Sharif University of Technology
Scientia Iranica
SCIENTIA
I RAN I CA
http://scientiairanica.sharif.edu

\title{
Tensile strength parameters controlling of zeolite-cemented sands
}

\author{
A. Khajeh ${ }^{a}$, H. Mola-Abasi ${ }^{b, *}$, and S. Naderi Semsani ${ }^{a}$ \\ a. Department of Civil Engineering, Lameie Institute, Gorgan, Iran. \\ b. Department of Civil Engineering, Gonbad University, Gonbad, Iran.
}

Received 3 February 2017; received in revised form 9 June 2017; accepted 19 August 2017

\section{KEYWORDS \\ Stabilization; \\ Zeolite; \\ Cement; \\ Tensile strength; \\ Babolsar sand.}

\begin{abstract}
Treating soil with cement and zeolite is widely used in soil stabilization. This research intends to quantify the impact of cement and zeolite contents, porosity index, and voids/cement ratio on zeolite cemented sands by the splitting tensile strength $\left(\sigma_{t}\right)$ assessment. The approach of splitting tensile tests using specimens by different zeolite replacement percentages was followed. Results indicated that cement was replaced by zeolite at optimum proportion of $30 \%$. Then, improved values of $\sigma_{t}$ by the effect of zeolite and cement chemical properties in the cement sand specimens were attained. Zeolite can have a more significant effect on a compacted mixture if its cement content and porosity increase. In this paper, it is shown that for the zeolite cemented sands, $\sigma_{t}$ increases by increase in cement content $(C)$ and reduction in porosity $(n)$; and a power function is welladapted to fit both $\sigma_{t}-C$ and $\sigma_{t}-n$. Afterwards, good correlations are obtained between voids/cement ratio $(n / c)$ and the splitting tensile strength $\left(\sigma_{t}\right)$ of the sand-zeolite-cement studied. Finally, based on a number of input variables, namely, porosity $(n)$, replacement of cement by zeolite $(Z)$, and cement content $(C)$, considering the regression approach, an equation is suggested to predict $\sigma_{t}$. Moreover, it is shown that the evolved equation could successfully predict the tensile strength.
\end{abstract}

(C) 2019 Sharif University of Technology. All rights reserved.

\section{Introduction}

Soil stabilization using cement has been adopted as a ground improvement approach in geotechnical engineering for several years. Using cemented soils is the most common procedure among others with a significant contribution to modifying of shear strength parameters of soil. There are some major advantages of cemented soils, among which the prominent cases include avoiding carrying soil from elsewhere and being

\footnotetext{
*. Corresponding author.

E-mail addresses: aghilekhajeh@yahoo.com (A. Khajeh); hma@gonbad.ac.ir (H. Mola-Abasi);

saforanaderii@gmail.com (S.Naderi Semsani)
}

doi: $10.24200 /$ sci. 2017.4585 cost-effective as well as time-saving. Cementation technique is widely used especially for treating problematic soils, e.g., loose sand. A number of parameters influencing mechanical behavior of cemented sands are cement content and its type, porosity, and grain size of the sandy soil. Several researchers have studied the properties of mechanical behavior of cement-sand mixture, some of which are presented in Table 1.

Cementation of sand contributes to increasing brittle behavior of the materials; thus, to reduce such constraints, some additives are used. The most popular applicable additives are fibres, including polypropylene and polyethylene [1-3]. Other additives used are nano particles, glass, fly ash, and silica fume [4-7]. In addition, using additives remarkably reduces the project cost. Yet, to date, in the studies, there has been a little heed paid to natural zeolite pozzolans as 
Table 1. Previous studies in the field of cemented sands.

\begin{tabular}{|c|c|c|c|}
\hline No. & Year & Authors & Description \\
\hline 1 & 2016 & Forcelini et al. [26] & $\begin{array}{l}\text { Axial and diametral compression tests are conducted on cemented sands and } \\
\text { it is shown that the higher the cement percentage and the smaller the void } \\
\text { ratio, the bigger is the resistance. }\end{array}$ \\
\hline 2 & 2015 & Yilmaz et al. [27] & $\begin{array}{l}\text { They investigate the specimen size effect on the strength properties of } \\
\text { cemented paste backfill through unconfined compressive strength tests [27]. }\end{array}$ \\
\hline 3 & 2014 & Consoli and Foppa [28] & $\begin{array}{l}\text { The adequacy of the porosity/cement ratio in predicting elastic and plastic } \\
\text { characteristics of an artificially cemented soil under isotropic compression } \\
\text { is examined. The results show that the porosity/cement ratio is useful in } \\
\text { estimating the incremental yield stress and initial bulk modulus of } \\
\text { artificially cemented soil in a certain circumstance [28]. }\end{array}$ \\
\hline 4 & 2013 & Consoli et al. [29] & $\begin{array}{l}\text { They measure the influence of distinct types of Portland cement, amounts } \\
\text { of cement, porosity, curing time period, and porosity/cement ratio in the } \\
\text { assessment of unconfined compressive strength of rammed sand-cement } \\
\text { mixtures [29]. }\end{array}$ \\
\hline 5 & 2010 & Consoli et al. [30] & $\begin{array}{l}\text { They quantify the influence of the amount of cement, the porosity, and the } \\
\text { voids/cement ratio in the assessment of unconfined compressive strength }\left(q_{u}\right) \\
\text { and splitting tensile strength }\left(q_{t}\right) \text { of an artificially cemented sand, as well as } \\
\text { in the evaluation of } q_{t} / q_{u} \text { relationship. The results show that a power function } \\
\text { adapts well } q_{t} \text { and } q_{u} \text { values with increasing cement content and reducing } \\
\text { porosity of the compacted mixture. The voids/cement ratio is demonstrated to } \\
\text { be an appropriate parameter to assess both } q_{t} \text { and } q_{u} \text { of the sand-cement } \\
\text { mixture studied. Finally, the } q_{t} / q_{u} \text { relationship is unique for the sand-cement } \\
\text { studied, being independent of the voids/cement ratio [30]. }\end{array}$ \\
\hline 6 & 2007 & Consoli et al. [17] & $\begin{array}{l}\text { They quantify the influence of the amount of cement, the porosity, and the } \\
\text { moisture content on the strength of an artificially cemented sandy soil and } \\
\text { evaluate the use of a water/cement ratio and a voids/cement ratio to assess } \\
\text { its unconfined compression strength. The results show that the unconfined } \\
\text { compression strength increases linearly with the growth of the cement } \\
\text { content and exponentially with the reduction in porosity of the compacted } \\
\text { mixture. The change in moisture content also has a marked effect on the } \\
\text { unconfined compression strength of mixtures compacted at the same dry } \\
\text { density }[17] \text {. }\end{array}$ \\
\hline 7 & 2005 & Thomé et al. [31] & $\begin{array}{l}\text { A new method is proposed for predicting the behavior of shallow footings } \\
\text { bearing on an upper layer of processed cemented soil that overlies a layer } \\
\text { of weakly bonded residual soil with a high void ratio [31]. }\end{array}$ \\
\hline
\end{tabular}

additives in cement-sand mixtures. Zeolite contains large quantities of $\mathrm{SiO}_{2}$ and $\mathrm{Al}_{2} \mathrm{O}_{3}$ particles [8]. Adding zeolite, like other pozzolanic materials such as calcined shale, calcined clay, or metakaolin, can greatly enhance the strength of cement due to pozzolanic reaction with $\mathrm{Ca}(\mathrm{OH})_{2}$ and prevent unpleasant expansion, which can be attributed to alkali-aggregate reaction. Zeolite addition will enhance the properties of interfacial microstructure and reduce the porosity of blended cement paste [8-10]. Yilmaz et al. concluded that the clinoptilolite blend decreased the specific gravity of cements [11]. 
Addition of zeolite to cement-sand mixtures can cause an increase in strain at failure as well as reduce their brittle behavior, that is, mixtures containing zeolite reveal increasing strain at failure in comparison with cemented ones. Additionally, by decreasing strain at failure, brittle behavior of the sample increases. Therefore, by using zeolite instead of cement, the brittle behavior of the mixture decreases [12]. MolaAbasi and Shooshpasha conducted a series of unconfined compressive tests [13] in order to investigate the effect of cement and zeolite on the mechanical behavior of sandy soils, and they concluded that cement addition substantially improved the soil strength of both zeolitecement mixtures and cemented soils, even in a low content [14]. The Unconfined Compression Strength (UCS) in any cement content first increased and then, after reaching the peak, decreased by zeolite replacement in 28 days of curing. The optimum value of zeolite for all cement contents was achieved 30\% at which zeolite efficiency was larger in mixtures which were more cemented and less compacted. MolaAbasi et al. [15] also performed Chemical Oxygen Demand (COD), pH, and Scanning Electron Microscopy (SEM) tests and confirmed that:

1. Materials with the zeolite mixture revealed stronger adsorptive capacity of COD than the cemented one did;

2. Cement substitution by zeolite increased the $\mathrm{pH}$ in 14 days and the $\mathrm{pH}$ variation of zeolite-cement samples stopped in 42 days;

3. Based on SEM analysis, zeolite addition to cementsand mixture improved the microstructure, which contributed to strength increase.

MolaAbasi and Shooshpasha presented a polynomial model for prediction of the Unconfined Compressive Strength (UCS) via Group Method of Data Handling (GMDH) type neural network defined by a number of major parameters including curing time, cement content, relative density, and zeolite replacement percentage. It was concluded that the most effective parameters on the amount of UCS were cement and zeolite contents [16].

Consoli et al. were able to develop the first reasonable dosage methodology regarding the porosity/cement ratio for soil-cement mixture, which was defined by the porosity of the compacted mixture separated by the volumetric cement content, as a suitable parameter to estimate the soil-cement mixture UCS [17]. MolaAbasi et al. found that the porosity/cement content ratio was an acceptable parameter in the UCS evaluation of zeolite-cemented sand and they presented a unique relationship linking the UCS to porosity and contents of zeolite and cement [18].
Nowadays, it is recognized that tensile strengths are intimately related in artificially cemented soils, see, e.g. [19-22]. In case of having an improved layer over a weak soil, once failure occurs, the failure undergoes tensile cracks in the bottom of the stabilized layer; hence, tensile strength estimation becomes a necessity. It is not still clear whether porosity has relation with zeolite and cement contents. This study intends to investigate controlling parameters of tensile strength, regarding zeolite-cement-sand mixtures. To achieve this end, parameters such as cement and zeolite contents, porosity, and porosity/cement ratio have been considered and a series of tensile tests have been done. Another objective of the current research is to investigate parameters which influence tensile strength. In this paper, first, the experimental setup, including material property definitions and test procedure, is explained. Then, effects of the mentioned controlling parameters on zeolite-cement sands are assessed. Finally, a unique correlation for the given zeolite-cement mixture is presented.

\section{Experimental setup}

The experimental setup of the current paper includes assessing material geotechnical properties and then, performing tensile strength tests. A series of splitting tensile tests involving three distinct porosity ratios, four cement contents $(2,4,6$, and $8 \%)$, and six different zeolite replacements $(0,10,30,50,70$, and $90 \%)$ have been performed.

\subsection{Materials}

\subsubsection{Sand}

The sand used in the present study was obtained from Babolsar city, which is located in northern Iran along the southern shoreline of Caspian Sea with a mean grain size of $D_{50}=0.24 \mathrm{~mm}$, coefficient of uniformity of $C_{u}=\frac{D_{60}}{D_{10}}=1.75$, coefficient of curvature of $C_{c}=$ 0.89 , maximum and minimum dry unite weights of $\gamma_{d, \max }\left(\mathrm{kN} / \mathrm{m}^{3}\right)=17.7$ and $\gamma_{d, \min }\left(\mathrm{kN} / \mathrm{m}^{3}\right)=14.9$, and specific gravity of $G_{s}=2.74$ [23]. According to the unified soil classification system, the soil is classified as poorly graded sand (SP) [24]. The grain size distribution of the sand is shown in Figure 1. A Scanning Electron Microscopy (SEM) picture of Babolsar sand with sub-rounded particles is shown in Figure 2(a).

\subsubsection{Cement}

Ordinary Portland cement type II (Figure 2(b)), from Neka cement companies in Iran, was employed. Some of its physical properties include: $G_{s}=3.11, S_{s} \geq$ $3000\left(\mathrm{~cm}^{2} / \mathrm{g}\right)$, and $S_{i} \geq 75(\mathrm{~min})$, where $G_{s}$ is specific gravity of the cement grains, $S_{s}$ is specific surface, and $S_{i}$ is initial setting time. Chemical properties of cement are presented in Table 2 [25]. 
Table 2. Chemical properties of the cement and zeolite.

\begin{tabular}{cccccccccc}
\hline \multicolumn{2}{c}{ Chemical name } & $\mathrm{SiO}_{\mathbf{2}}$ & $\mathrm{Al}_{\mathbf{2}} \mathbf{O}_{\mathbf{3}}$ & $\mathbf{F e}_{\mathbf{2}} \mathrm{O}_{\mathbf{3}}$ & $\mathbf{K}_{\mathbf{2}} \mathbf{O}$ & $\mathbf{C a O}$ & $\mathbf{M g O}$ & $\mathbf{S O}_{\mathbf{3}}$ & $\mathrm{Na}_{\mathbf{2}} \mathrm{O}$ \\
\hline \multirow{2}{*}{ Percent (\%) } & Cement & 21.90 & 4.86 & 3.3 & 0.63 & 63.32 & 1.2 & 2.04 & 3.08 \\
& Zeolite & 67.44 & 10.8 & 0.84 & 0.19 & 1.24 & 0.33 & 0.47 & 3.71 \\
\hline
\end{tabular}

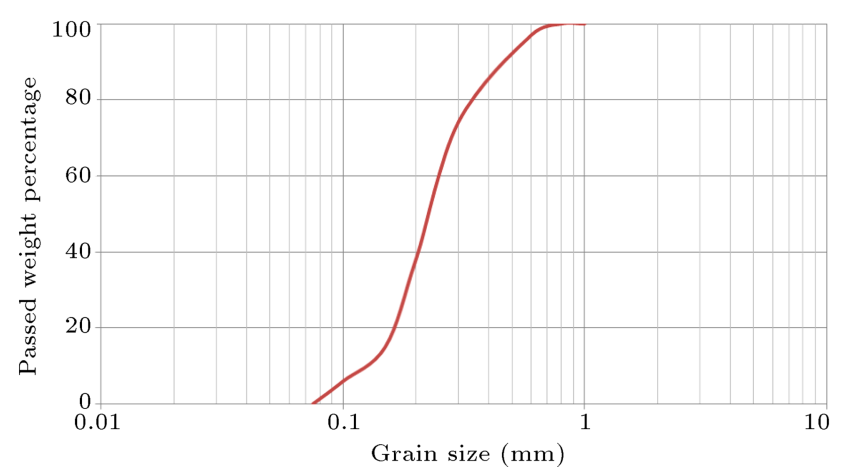

Figure 1. Grain size distribution of the studied sand.

\subsubsection{Zeolite}

Natural clinoptilolite type of zeolite with particles passing No. 200 sieve, known as fine aggregates, was used in this study. It can be found near Aftar City in Semnan province of Iran (Figure 2(c) and Table 2). According to the Unified Soil Classification System, zeolite is classified as silt (ML). Furthermore, it is considered to be non-plastic $(L L=24 \%)$ and its physical terms are: specific weight $=11900\left(\mathrm{~N} / \mathrm{m}^{3}\right)$, specific surface $=$ $100\left(\mathrm{~m}^{2} / \mathrm{kg}\right)$, water absorption $=60 \%$ volumetric, cation exchange capacity $=26(\mathrm{gr} / \mathrm{meq})$, and $G_{s}=2.2$.

\subsection{Sample preparation}

Favorable impact of zeolite on cemented sand strength requires curing time due to pozzolanic reaction. The pozzolanic activity of zeolites with cement can be attributed to their chemical and mineralogical composition. Based on the test results of MolaAbasi et al., 42 days of curing time could be considered to stop $\mathrm{pH}$ variation of zeolite samples. Therefore, 42 days is the time that the maximum hydration reaction differences between zeolite-cemented sand and mere-cemented sand occur; so it was selected as an appropriate curing time for subsoil improvements [15]. It is noteworthy that, in sample preparation, the effect of cement and zeolite addition was assumed as follows.

To prepare cylindrical specimens, with regard to the considered mixtures (cement percent was 2, 4, 6, and $8 \%$ as well as $0,10,30,50,70$, and $90 \%$ zeolite replacement), dry weight of materials including sand, cement, and zeolite weights could be calculated from Eq. (1). For tensile specimens, zeolite replacement was $30 \%$ based on unconfined compressive strength.

$$
W_{s}=\gamma_{d} \times \forall,
$$

where $\forall$ is the mold volume and $\gamma_{d}$ is the dry unit weight related to 50,70 , and 85 relative densities of sand. It is important to note that cement addition leads to increase in initial density of specimens. To consider this agent in dry weight of samples, the following steps were performed:

- Considering minimum and maximum void ratios of the sand, the void ratios of 50, 70, and 85 relative densities were computed;

- $G_{s}$ of the mixture of sand, cement, and zeolite was determined using weighted average;

- The unit weight of considered mixture was calculated by Eq. (2):

$$
\gamma_{d}=\frac{G_{s} \gamma_{w}}{1+e}
$$

Before testing, sample preparation inside a lubricated cylindrical mold was performed. In Figure 3, a typical specimen with $36 \mathrm{~mm}$ diameter and $76 \mathrm{~mm}$ height is shown. During preparation, first, dry materials as in Figure 4 were mixed and water was added; then, they were stored in a container and a plastic bag to avoid moisture loss before testing.

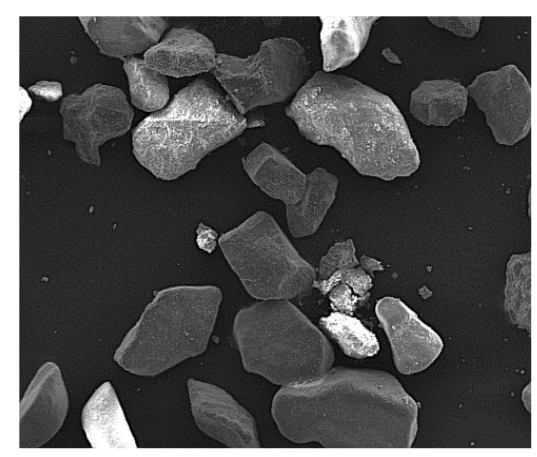

(a)

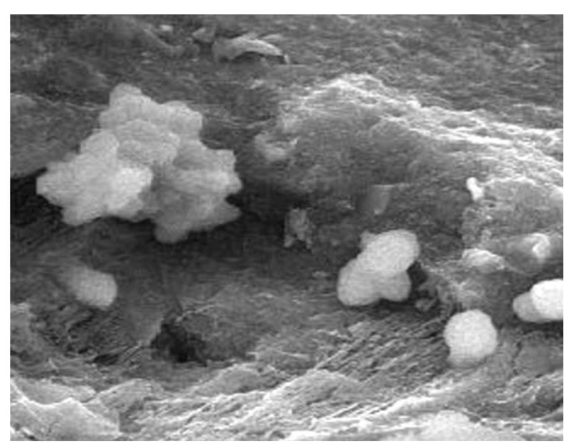

(b)

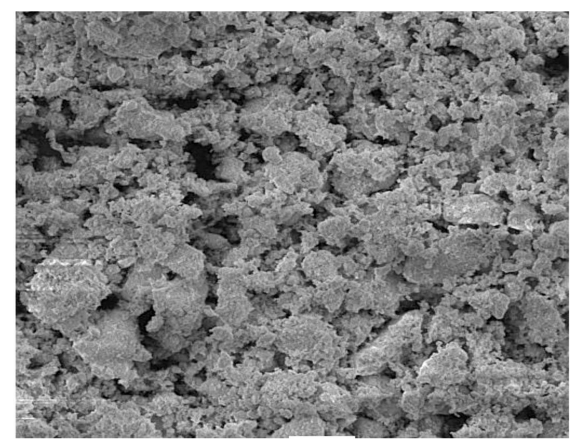

(c)

Figure 2. SEM images of (a) Babolsar sand, (b) cement, and (c) zeolite. 


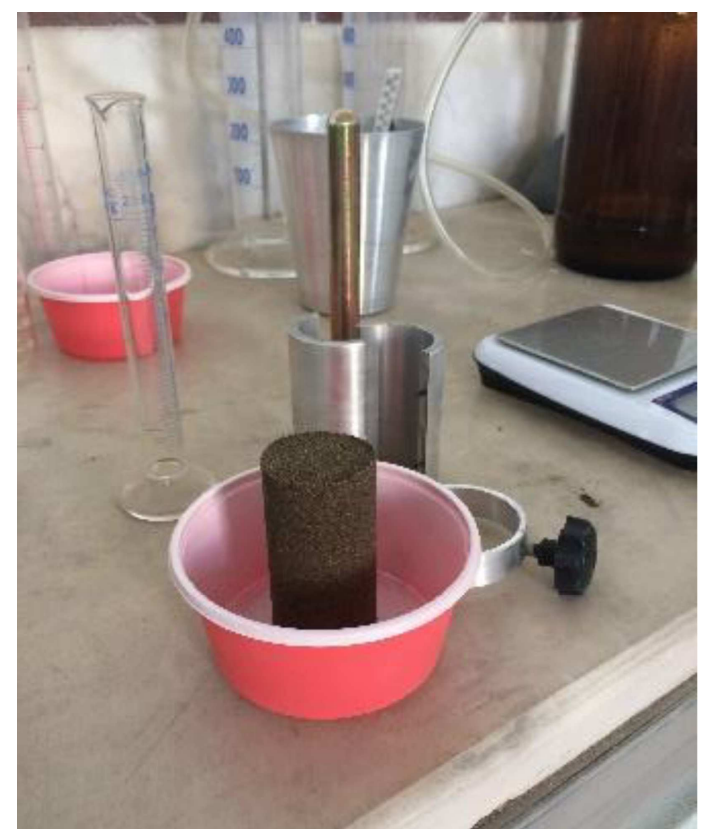

Figure 3. The mold and the prepared sample.

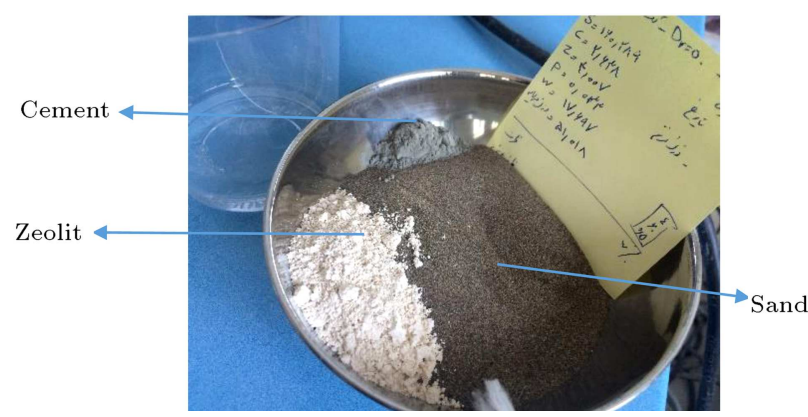

Figure 4. A typical dry material.

\subsection{Test procedure}

A series of splitting tensile tests were performed in this study according to Brazilian standard (NBR 7222 Brazilian Standard Association 1983). All of the parameters considered in the testing setup are listed in Table 3.

For the splitting tensile tests, an automatic load-

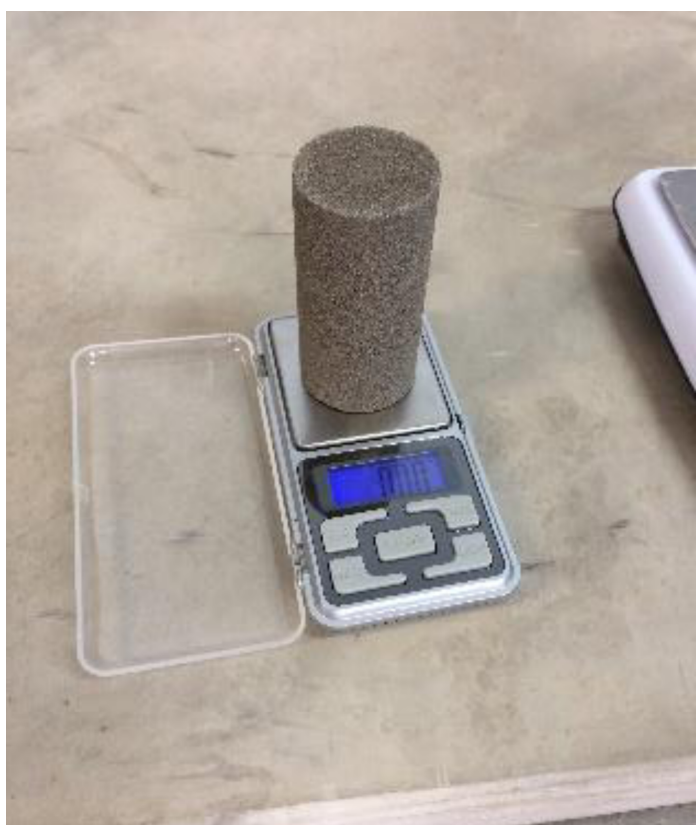

Figure 5. Measuring the sample weight before testing.

ing machine with the capacity of up to $5 \mathrm{kN}$ was used. In Figure 5, the weight of remolded specimen was measured. Dimensions were also determined; all dimensions were about $76 \mathrm{~mm}$ in height and $38 \mathrm{~mm}$ in diameter. Then, the remolded specimen was positioned in the machine. At a specific loading, its failure was utterly seen in vertical diameter of the sample. These are depicted in Figure 6(a) and (b), respectively.

\section{Results}

\subsection{Effect of zeolite content on tensile strength}

Variations of tensile strength related to the 42- days cured samples by different relative densities are plotted against zeolite replacements percent $(Z \%)$ in Figure 7 . Figure 7 indicates the effect of additive materials on sand in relation to $\sigma_{t}$ determination; as can be clearly seen, in any range of cement $(2,4,6$, and $8 \%), \sigma_{t}$ has

Table 3. Description of parameters.

\begin{tabular}{ll}
\hline \multicolumn{1}{c}{ Variable } & \multicolumn{1}{c}{ Samples description } \\
\hline Soil type & Poorly graded sand \\
Cement agent & Portland cement (type II) \\
Cement content & $2,4.6$, and $8 \%$ dry unit weights of base soil \\
Type of zeolite & Natural cilnoptilolite zeolite \\
Zeolite content & $0,10,30,50,70$, and $90 \%$ of cement \\
Voids ratio & Related to Dr=50, 70, and $85 \%$ sand \\
Water content & $10 \%$ weight of base soil \\
Sample size & 38 mm diameter and 76 mm height \\
Curing condition & Cured for 42 days in humid room \\
\hline
\end{tabular}




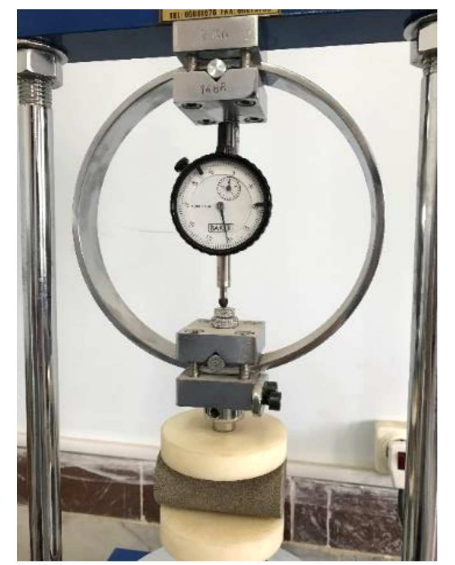

(a)

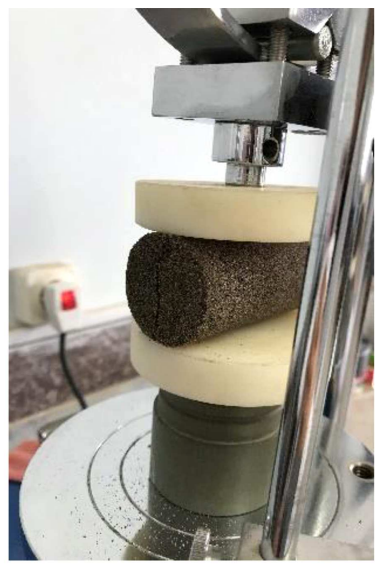

(b)
Figure 6. (a) Before testing and (b) after testing.

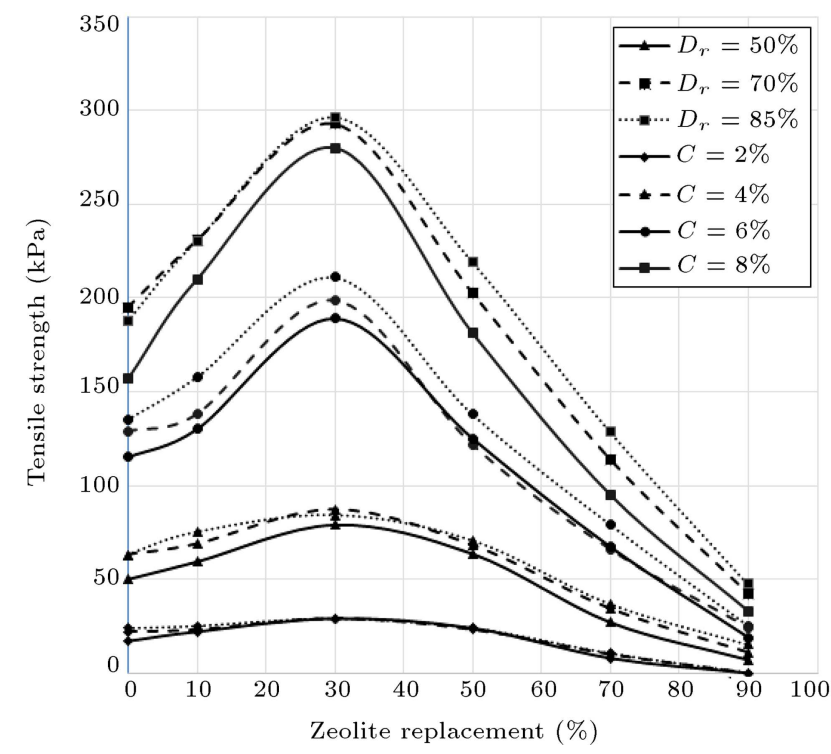

Figure 7. Effect of additive materials to sand on tensile strength $\left(\sigma_{t}\right)$.

Table 4. Chemical properties of the cement replaced by $30 \%$ zeolite.

\begin{tabular}{ccccc}
\hline \multicolumn{2}{c}{ Chemical name } & $\mathbf{S i O}_{\mathbf{2}}$ & $\mathbf{A l}_{\mathbf{2}} \mathbf{O}_{\mathbf{3}}$ & $\mathbf{C a O}$ \\
\hline & 0.7 cement & 15.33 & 3.402 & 44.324 \\
Percent (\%) & 0.3 zeolite & 20.232 & 3.24 & 0.372 \\
& Sum & 35.562 & 6.642 & 44.696 \\
& & \multicolumn{2}{c}{42.204} & 44.696 \\
\hline
\end{tabular}

grown. Later on, reaching a summit of $30 \%$ zeolite replacement, there is a drop. Results show that the optimum percent of zeolite achieved is $30 \%$. Therefore, substitution of $30 \%$ zeolite is enough to generate a significant gain in strength. The causes may be related to chemical properties of zeolite and cement mixture. Once $30 \%$ zeolite is replaced by cement, the sum of $\mathrm{SiO}_{2}$ and $\mathrm{Al}_{2} \mathrm{O}_{3}$ amounts is close to $\mathrm{CaO}$ (Table 4).

The rate of increase in $q_{t}$ of optimum

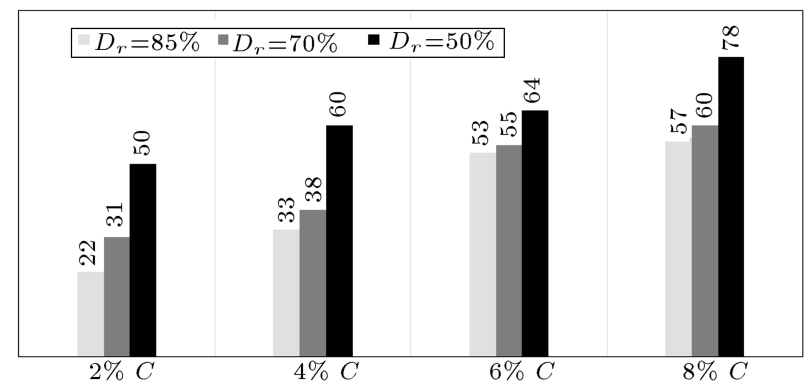

Figure 8. $\sigma_{t}$ enhancement of cemented sands replaced by optimum value of zeolite.

zeolite-cemented sand samples in comparison with cemented ones ( $\left[\sigma_{t}\right.$ zeolite cemented sand -

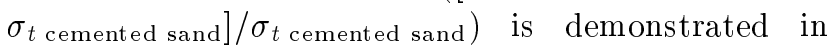
Figure 8. It is plainly visible that mixtures having higher cement contents and lower densities experienced much more rise in their strength rates, which can be traced to the fact that the amount of zeolite-cement hydration is much more higher in low densities.

Moreover, it is evident from Figure 4 that when $Z=50 \%$, all $q_{t}$ amounts approximately reached cemented sand tensile strength, representing that using zeolite had the same effect on the strength. Cement production process in Iran is highly expensive and time-consuming and it induces much pollution. In addition, there are a number of benefits in using zeolite; for instance, zeolite addition to cemented mixtures increases initial setting time as well as shear strain and reduces brittle behavior [15]. Therefore, the use of zeolite sounds essential and can be included as one of the environmentally sound practices.

\subsection{Effect of cement content on tensile strength}

Figure 9 shows the raw data for the three studied porosity ratios and the fitted lines for $\sigma_{t}$ as a function

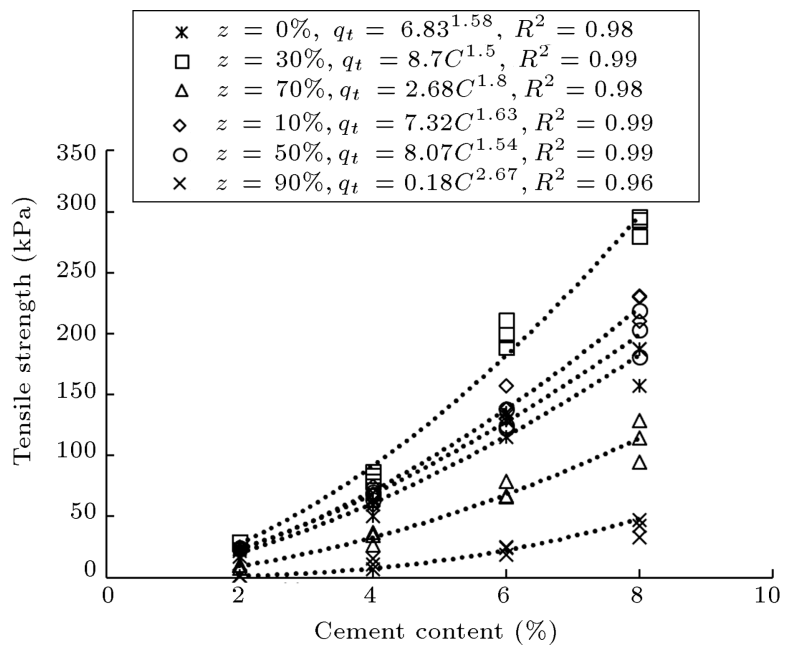

Figure 9. Variations of splitting tensile strength with cement and zeolite changes. 
of cement content $(C)$ for different ranges of zeolite percent. It can be observed from Figure 9 that cement content parameter has great effect on the $\sigma_{t}$ value of this sand-cement-zeolite mixture, that is, even a small addition of cement generates a considerable rise in strength rate. Each line in the figure is a best fit line, demonstrating that the power correlation could accurately predict the tensile strength.

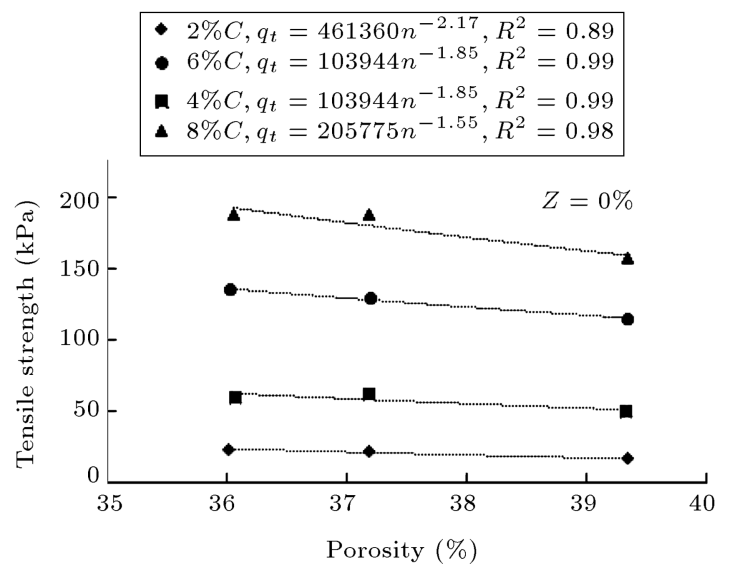

(a)

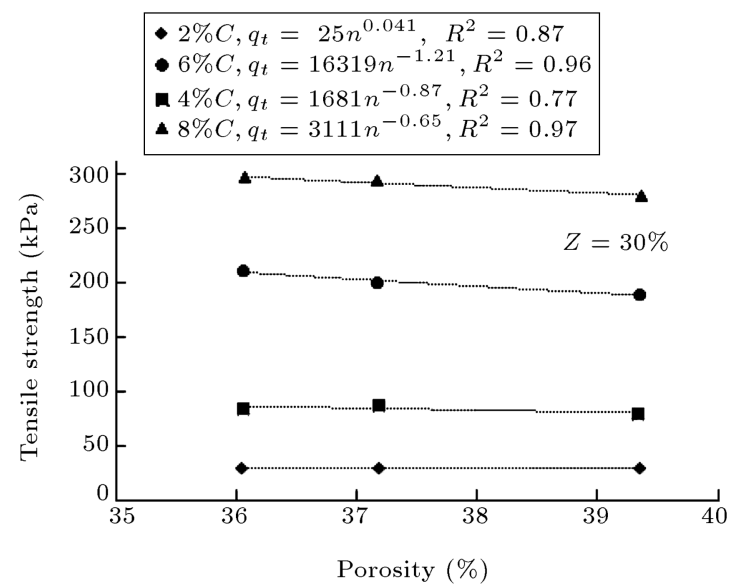

(c)

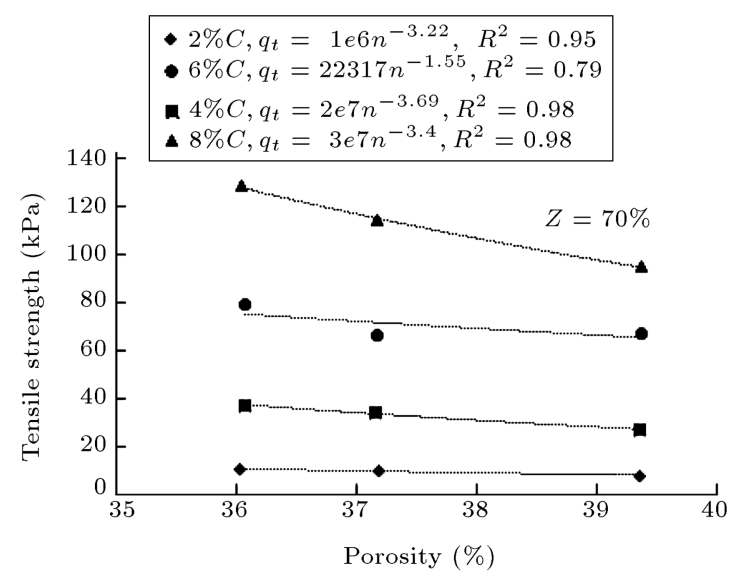

(e)

\subsection{Effect of porosity on tensile strength}

Tensile strength variations of zeolite-cement-sand specimens on vertical axis are plotted against porosity $(n)$ in each diagram drawn in Figure 10 . It is seen that the amount of $\sigma_{t}$ decreases while the rate of porosity increases in both zeolited and cemented samples. Strength rate losses are more for cemented mixtures and less for zeolite-cemented ones. As it can

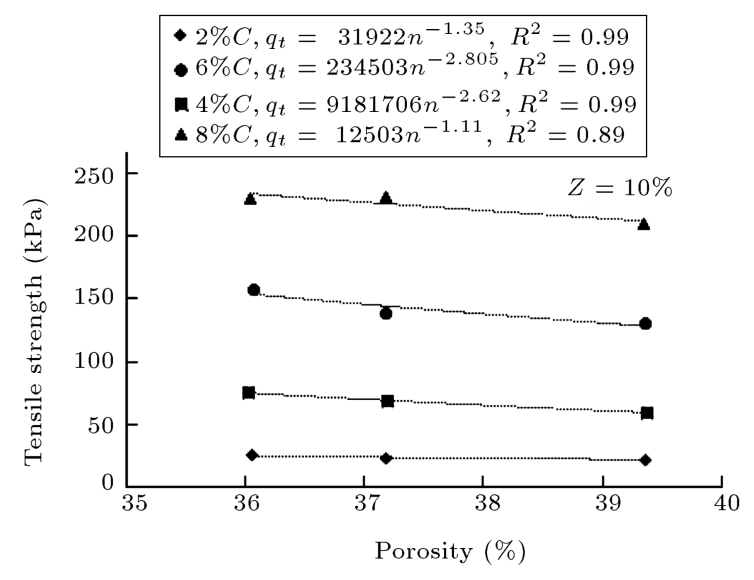

(b)

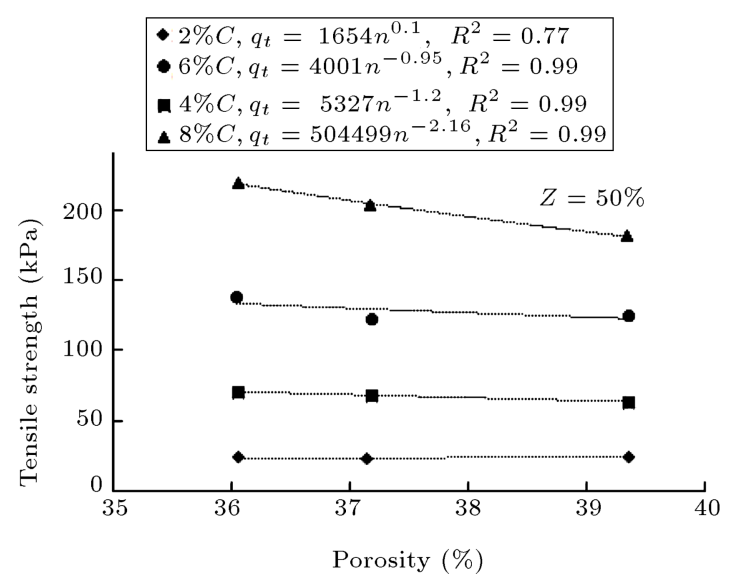

(d)

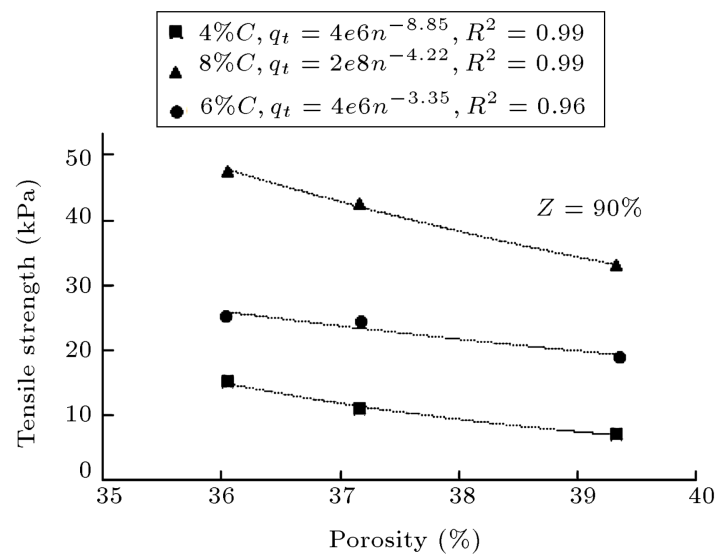

(f)

Figure 10. $\sigma_{t}$ variations against porosity for the zeolite-cement samples. 
be clearly seen in Figure 10(a), (b), (c), and to some extent (d), while $n$ is increasing, $\sigma_{t}$ remains roughly consistent. In other words, once cement is substituted by optimum zeolite content $(30 \%), \sigma_{t}$ remains constant while porosity is increasing. Therefore, the more the porous blends, the more the effective zeolite usage is. Thus, in order to provide a mixture that meets the strength required by the project, an engineer can use less amount of cement as well as less compaction energy. In Figure 10, each line can be one of the best fit lines, demonstrating that a power function conforms well to the relation $\sigma_{t}-n$.

It is important to note that when $Z=90 \%$, there is no line related to $2 \%$ cement, which illustrates that $\sigma_{t}$ in these cases is not accessible. Moreover, the samples are so weak and loose that break easily.

\subsubsection{Effect of voids/cement ratio on tensile strength}

Figure 11 depicts the variation of splitting tensile strength against the voids/cement ratio (defined by $(n / C)$, where $n$ is porosity and $C$ is cement content). It can be suggested that the voids/cement ratio is one of the key contributing parameters to predict $\sigma_{t}$. Good correlations can be observed between this ratio $(n / c)$ and the splitting tensile strength $\left(\sigma_{t}\right)$ of the sandzeolite-cement studied (see Eqs. (3)-(8)):

$$
\begin{array}{lll}
Z=0 \%, & \sigma_{t}=1881 \times(n / C)^{-1.52}, & R^{2}=0.99, \\
Z=10 \%, & \sigma_{t}=2280 \times(n / C)^{-1.51}, & R^{2}=0.99, \\
Z=30 \%, & \sigma_{t}=3059 \times(n / C)^{-1.53}, & R^{2}=0.99, \\
Z=50 \%, & \sigma_{t}=2073 \times(n / C)^{-1.52}, & R^{2}=0.99, \\
Z=70 \%, & \sigma_{t}=1122 \times(n / C)^{-1.51}, & R^{2}=0.98, \\
Z=90 \%, & \sigma_{t}=393 \times(n / C)^{-1.5}, & R^{2}=0.97 .
\end{array}
$$

It is fairly straightforward in the equations that although the exponents are almost constant in all zeolite replacements $(\approx-1.51)$, the coefficients are

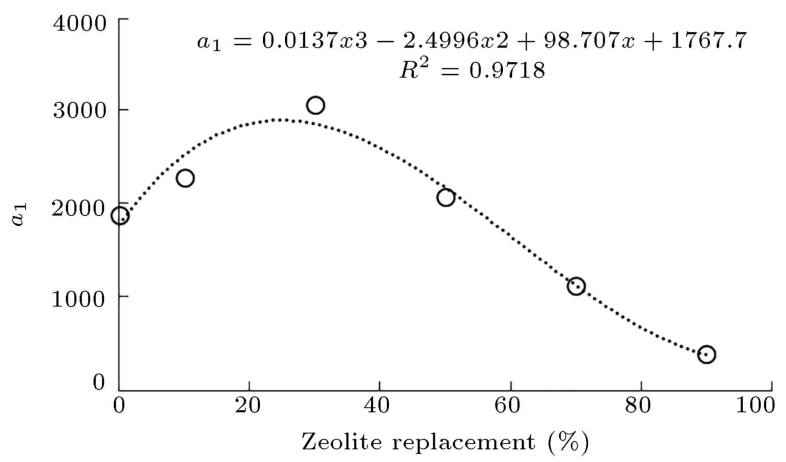

Figure 12. Variations of $a_{1}$ coefficient with zeolite replacement.

changing. Generalizing all the aforementioned equations, Eq. (7) is achieved as follows:

$$
\sigma_{t}=a_{1} \times(n / C)^{-1.51} \text {. }
$$

The values of $a_{1}$ by zeolite variation are presented in Figure 12.

In this figure, it can be clearly seen that when zeolite rate grows up to $30 \%, a_{1}$ experiences its maximum value $(\approx 3080)$ and afterwards, it drops dramatically, which was predictable based on Figure 3. In addition, the changes of $a_{1}$ are polynomial; hence, the power of correlation can be considered -1.51 and variations of corrected splitting tensile strength, $\sigma_{t} / a_{1}$, with voids/cement ratio could be achieved by Figure 13 with the correlation coefficient higher than $0.98 \%$.

Finally, based on a number of input variables, namely, porosity $(n)$, replacement of cement by zeolite $(Z)$, and cement content $(C)$, considering the regression approach, an equation is suggested to predict $\sigma_{t}$. The developed model is:

$$
\sigma_{t}=\left(2099+111 Z-2.81 z^{2}\right) \times(n / C)^{-1.62} .
$$

Figure 14 shows scatter diagram for the estimated $\sigma_{t}$ from the application of the proposed equation (Eq. (10)) and the measured values from the tensile strength tests. The model shows a very good cor-
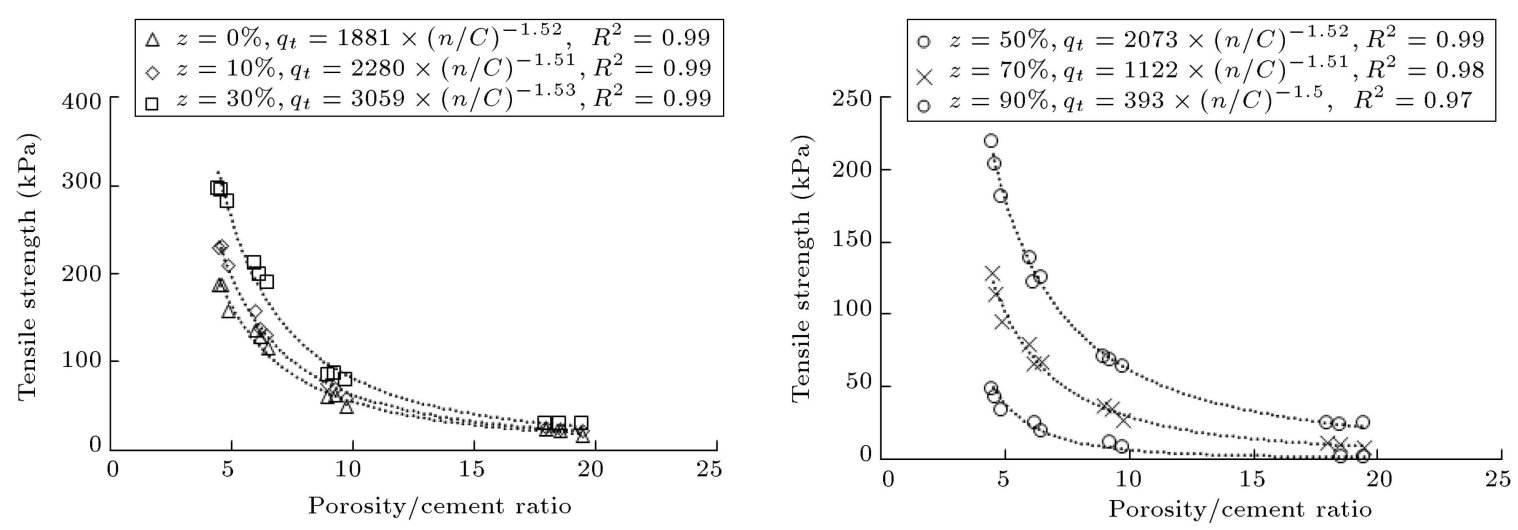

Figure 11. Variations of splitting tensile strength against voids/cement ratio for various zeolite percent. 


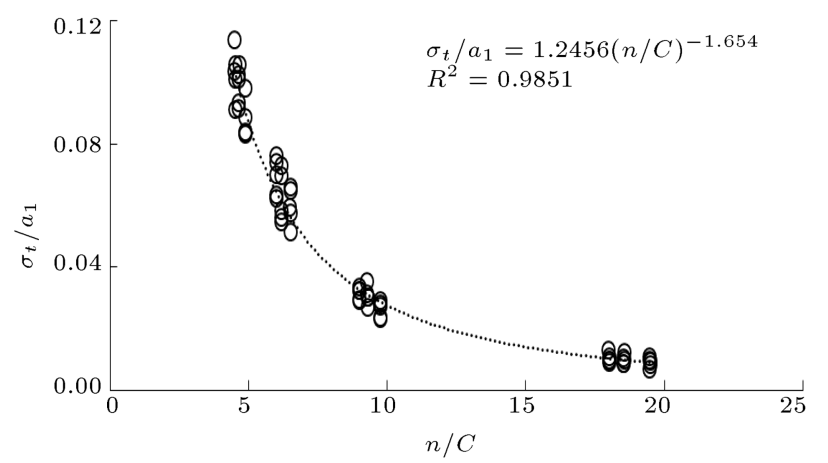

Figure 13. Variations of corrected splitting tensile strength, $\sigma_{t} / a_{1}$, with voids/cement ratio.

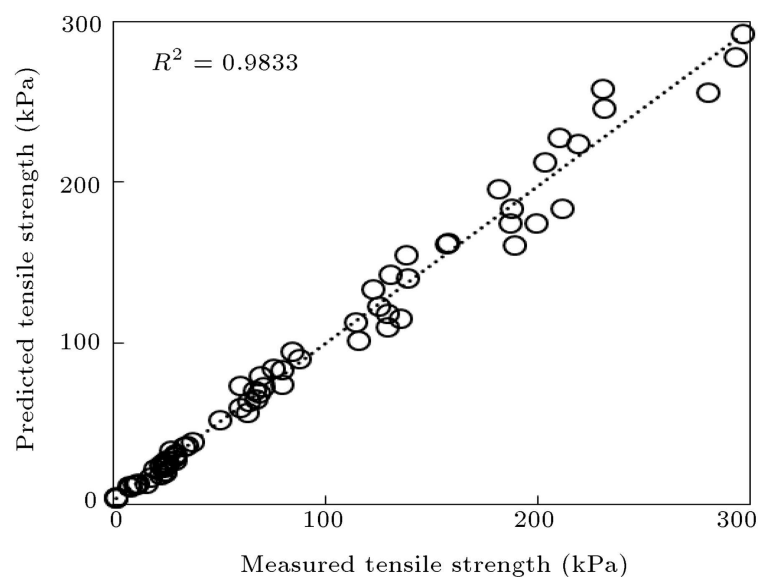

Figure 14. Comparison between the measured and predicted $\sigma_{t}$ using Eq. (10).

relation and the proposed equation results in points closely located around the 1:1 line. It is clearly evident that the evolved equation could successfully predict $\sigma_{t}$.

\section{Conclusions}

A topic that has received a considerable attention is identifying the behavior of soil in tension. Knowing tensile characteristics of soils and estimation of the tensile strength can be a significant contribution to avoid inevitable consequences in tensile zones, namely, fill dams, retaining walls, and soil slopes. In the case of problematic soils, soil stabilization is a common approach in order to enhance tensile strength and cement is the most common addition to do so. However, it is found that using zeolite instead of cement increases tensile strength $\left(\sigma_{t}\right)$ in the cemented mixture. Other main results include:

- For both zeolite-cemented and mere-cemented soils, cement addition, either in minor quantities or more, improves the soil strength substantially. With respect to the samples in which cement was replaced by zeolite, considering 42 days of curing time, $\sigma_{t}$ showed an increasing trend up to $30 \%$ zeolite replacement and a decreasing one afterwards;

- When cement was replaced by $30 \%$ zeolite, the amounts of $\mathrm{SiO}_{2}$ and $\mathrm{AlO}_{3}$ were shown to be close to $\mathrm{CaO}$, which proved that it could be the optimum value for the applicable pozzolanic reaction contributing to the target strength;

- Tensile strength of soil-cement mixtures by $30 \%$ zeolite replacement reached its maximum value. In other words, the optimum value of zeolite replacement for any type of cement content was 30\%, at which $\sigma_{t}$ increased from $22 \%$ to $78 \%$;

- Once cement was replaced by $Z=50 \%$, it was observed that the mixture provided the same strength as mere-cemented samples did. Hence, as zeolite is cheaper in Iran and induces less pollution, it is recommended to be used as strengthening agent;

- The rate of strength gain increased by lower density as well as higher cement content, that is, adding zeolite was more efficient in less compacted mixtures as well as higher cemented ones;

- Reducing the rate of compacted mixture porosity, the strength of cemented soils and zeolite-cement mixtures improved substantially and moderately, respectively;

- The proposed equation for $\sigma_{t}$ in the current study is $\sigma_{t}=\left(2099+111 Z-2.81 z^{2}\right) \times(n / C)^{-1.62}$.

Generally, based on the significant advantages mentioned in this research, it is strongly recommended to use zeolite as one of the additives in order to strengthen problematic soils. Moreover, the results presented in this paper suggest that by using the voids/cement ratio $(n / c)$ for a given zeolite content (0 to $90 \%$ zeolite replacement), an engineer can take the amounts of zeolite, cement, and compaction energy in accordance with the necessities of providing a mixture that meets the strength required by the project at the optimum cost. The voids/cement ratio can also be useful in the field control of zeolite-soil-cement layers.

\section{Nomenclature}

$\begin{array}{ll}\sigma_{t} & \text { Tensile strength } \\ n & \text { Porosity } \\ C_{c} & \text { Coefficient of curvature } \\ C_{u} & \text { Coefficient of uniformity } \\ Z & \text { Zeolite content } \\ C & \text { Cement content } \\ G_{s} & \text { Specific gravity } \\ S_{i} & \text { Initial setting time } \\ S_{s} & \text { Specific surface }\end{array}$




\section{References}

1. Festugato, L., Menger, E., Benezra, F., Kipper, E.A., and Consoli, N.C. "Fibre-reinforced cemented soils compressive and tensile strength assessment as a function of filament length", Geotext. Geomembranes, 45(1), pp. 77-82 (2017).

2. Pino, L.F.M. and Baudet, B.A. "The effect of the particle size distribution on the mechanics of fibrereinforced sands under one-dimensional compression", Geotext. Geomembranes., 43(3), pp. 250-258 (2015).

3. Consoli, N.C., Prietto, P.D.M., and Ulbrich, L.A. "Influence of fiber and cement addition on behaviour of sandy soil", J. Geotech. Geoenvironmental Eng., 124(1211-1214), pp. 197-210 (1998).

4. Choobbasti, A.J., Vafaei, A., and Kutanaei, S.S. "Mechanical properties of sandy soil improved with cement and nanosilica", Open Eng., 5(1), pp. 111-116 (2015).

5. Arabani, M., Sharafi, H., Habibi, M.R., and Haghshenas, E. "Laboratory evaluation of cement stabilized crushed glass-sand blends", Electron. J. Geotech. Eng., 17, pp. 1777-1792 (2012).

6. Consoli, N.C., Consoli, B.S., and Festugato, L. "A practical methodology for the determination of failure envelopes of fiber-reinforced cemented sands", Geotext. Geomembranes., 41, pp. 50-54 (2013).

7. Ateş, A. "Mechanical properties of sandy soils reinforced with cement and randomly distributed glass fibers (GRC)", Compos. Part B Eng., 96, pp. 295-304 (2016).

8. Poon, C.S., Lam, L., Kou, S.C., and Lin, Z.S. "A study on the hydration rate of natural zeolite blended cement pastes", Constr. Build. Mater., 13(8), pp. 427432 (1999).

9. Feng, N.-Q., Li, G.-Z., and Zang, X.-W. "Highstrength and flowing concrete with a zeolitic mineral admixture", Cem. Concr. Aggregates., 12(2), pp. 6169 (1990).

10. Canpolat, F., Yılmaz, K., Köse, M.M., Sümer, M., and Yurdusev, M.A. "Use of zeolite, coal bottom ash and fly ash as replacement materials in cement production", Cem. Concr. Res., 34(5), pp. 731-735 (2004).

11. Yłlmaz, B., Uçar, A., Öteyaka, B., and Uz, V. "Properties of zeolitic tuff (clinoptilolite) blended Portland cement", Build. Environ., 42(11), pp. 3808-3815 (2007).

12. Mola-Abasi, H. and Shooshpasha, I. "Influence of zeolite and cement additions on mechanical behavior of sandy soil", J. Rock Mech. Geotech. Eng., 8(5), pp. 746-752 (2016).

13. ASTM, D., 2166 (1985), Standard Test Method for Unconfined Compressive Strength of Cohessive Soil, In American Society for Testing and Materials (2000).

14. MolaAbasi, H. and Shooshpasha, I. "Prediction of zeolite-cement-sand unconfined compressive strength using polynomial neural network", Eur. Phys. J. Plus., 131(4), pp. 1-12 (2016).
15. Mola-Abasi, H., Kordtabar, B., and Kordnaeij, A. "Effect of natural zeolite and cement additive on the strength of sand", Geotech. Geol. Eng., 34(5), pp. 1539-1551 (2016).

16. Mola-Abasi, H. and Shooshpasha, I. "Polynomial models controlling strength of zeolite-cement-sand mixtures", Sci. Ir., Trans Civil Eng., 24(2), p. 526 (2017).

17. Consoli, N.C., Foppa, D., Festugato, L., and Heineck, K.S. "Key parameters for strength control of artificially cemented soils", J. Geotech. Geoenvironmental Eng., 133(2), pp. 197-205 (2007).

18. Mola-Abasi, H., Kordtabar, B., and Kordnaeij, A. "Parameters controlling strength of zeolite-cementsand mixture", Int. J. Geotech. Eng., 11(1), pp. 72-79 (2017).

19. Clough, G.W., Sitar, N., Bachus, R.C., and Rad, N.S. "Cemented sands under static loading", J. Geotech. Geoenvironmental Eng., 107, pp. 789-847 (1981).

20. Consoli, N.C., Prietto, P.D.M., Carraro, J.A.H., and Heineck, K.S. "Behavior of compacted soil-fly ashcarbide lime mixtures", J. Geotech. Geoenvironmental Eng., 127(9), pp. 774-782 (2001).

21. Toll, D.G. and Ali Rahman, Z. "Critical state shear strength of an unsaturated artificially cemented sand", Géotechnique, 67(3), pp. 1-8 (2016).

22. Hashemi, S.S., Melkoumian, N., Taheri, A., and Jaksa, M. "The failure behaviour of poorly cemented sands at a borehole wall using laboratory tests", Int. J. Rock Mech. Min. Sci., 77, pp. 348-357 (2015).

23. Holtz, R.D., Kovacs, W.D., and Sheahan, T.C., An Introduction to Geotechnical Engineering, 2nd Ed., Pearson, Upper Saddle River, NJ (2011).

24. Standard, A., "Standard practice for classification of soils for engineering purposes (unified soil classification system)", In Annual Book of ASTM Standards. ASTM, International West Conshohocken, PA (2010).

25. ASTM, C. 150, Standard Specification for Portland Cement, Annu. B. ASTM Stand., 4, pp. 221-236 (2002).

26. Forcelini, M., Garbin, G.R., Faro, V.P., Consoli, N.C. "Mechanical behavior of soil cement blends with Osorio sand", Procedia Engineering, 143, pp. 75-81 (2016)

27. Yilmaz, E., Belem, T., and Benzaazoua, M. "Specimen size effect on strength behavior of cemented paste backfills subjected to different placement conditions", Eng. Geol., 185, pp. 52-62 (2015).

28. Consoli, N.C. and Foppa, D. "Porosity/cement ratio controlling initial bulk modulus and incremental yield stress of an artificially cemented soil cured under stress", Géotech Lett., 4, pp. 22-26 (2014).

29. Consoli, N.C., Festugato, L., da Rocha, C.G., and Cruz, R.C. "Key parameters for strength control of rammed sand-cement mixtures: Influence of types of portland cement", Constr. Build. Mater., 49, pp. 591597 (2013). 
30. Consoli, N.C., Cruz, R.C., Floss, M.F., and Festugato, L. "Parameters controlling tensile and compressive strength of artificially cemented sand", J. Geotech. Geoenvironmental Eng., 136(5), pp. 759-763 (2009).

31. Thomé, A., Donato, M., Consoli, N.C., and Graham, J. "Circular footings on a cemented layer above weak foundation soil", Can. Geotech. J., 42(6), pp. 15691584 (2005).

\section{Biographies}

Aghileh Khajeh received her MSc degree in Geotechnical Engineering from the Lameie Institute, Gorgan, Iran, in 2017. Her research interests include in-situ testing, soil improvement, and cemented sands.
Hossein Mola-Abasi received his MSc and $\mathrm{PhD}$ degrees in Geotechnical Engineering from University of Guilan and Babol University of Technology, Iran, in 2010 and 2016, respectively, and is currently Assistant Professor at Gonbad University. His research interests include soil improvement techniques, soft computing in geomechanics with special focus on earthquake geotechnical engineering, and the dynamic behavior of soils.

Safora Naderi Semsani received her MSc degree in Geotechnical Engineering from the Lameie Institute, Gorgan, Iran, in 2017. Her research interests include in-situ testing, soil improvement, and cemented sands. 